\title{
Studying Corrosion Behavior of Recrystallization Treatment of AA 5083 and AA 5085 Aluminium Alloys in Tigris and Shatt Al Arab
}

\author{
Sahib M. Mahdi ${ }^{1}$, Israa R. Mohammed ${ }^{2}$ \\ ${ }^{1}$ saheb.m.mahdi@uomustansiriyah.edu.iq, ${ }^{2}$ israaryadh8494@gmail.com \\ ${ }^{1,2}$ Department of material engineering, college of engineering, Mustansiriyah University, Baghdad, Iraq
}

\begin{abstract}
In this study, the corrosion behaviour of both AA 5083 and AA 5086 aluminium alloys in the marine environment was investigated in the Tigris and Shatt Al Arab water media before and after recrystallization annealing at room temperature $\left(23^{\circ} \mathrm{C}\right)$. The corrosion resistance of AA 5083 marine aluminium alloy shows an improvement after recrystallization at a temperature of $350^{0} \mathrm{C}$ for 15 minutes from $\left(708.5 \times 10^{-6}\right)$ to $\left(513 \times 10^{-6} \mathrm{mmpy}\right)$ in Tigris, while in Shat Al Arab the improvement was from $\left(1.84 \times 10^{-5}\right)$ to $\left(217.7 \times 10^{-6} \mathrm{mmpy}\right)$ using the Tafel test. While the corrosion resistance in AA5086 decreased in both Shat Al Arab and Tigris River, in Tigris the decreasing was from $\left(1.259 \times 10^{-3}\right)$ to $\left(7.418 \times 10^{-3} \mathrm{mmpy}\right)$, while in Shat $\mathrm{Al}$ Arab the decreasing was from $\left(28.25 \times 10^{-6}\right)$ to $\left(305 \times 10^{-6} \mathrm{mmpy}\right)$. Both alloys suffered from uniform corrosion in the Tigris River. In Shat Al Arab both alloys suffered from pitting corrosion. Hardness for both alloys shows decreasing after recrystallization annealing.
\end{abstract}

Keywords: marine aluminium alloys; Tigris River; Shatt Al Arab River; corrosion behaviour; Tafel test.

\section{Introduction}

Al-Mg alloys are considered as non-heat treatable alloys with moderate strength. They can be strengthened either by solid solution[1] or by cold work strain hardening [2]. Al-Mg alloys are used in many applications such as trailers, cryogenic tanks and especially in building various parts in ships and boats [3, 4], because of their low density, high corrosion resistance and good mechanical properties [5-9]. The corrosion resistance of Al-Mg alloys is owed to oxide film formation as this layer under atmospheric condition will improve [10]. This layer is thin, non-coherent and nonuniform. Some factors like the film type that has been formed, the existence of aggressive anion and some unknown factor [11] will affect the film growth rate or it will affect the film quality that plays an important role in the breakdown of the film. The breakdown of this layer will result in pitting and crevice corrosion $[12,13]$. Al-Mg alloys have a heterogeneous microstructure so these alloys will undergo pitting corrosion $[14,15]$.

Pitting corrosion is formed in the aluminium alloy in saltwater because of the existence of precipitate. These precipitates will lead to ions transformation and this will result in the formation 
of a weak oxidation layer [16]. Temperature, $\mathrm{Cl}$ concentration and $\mathrm{PH}$ concentration of the solution will also initiate pitting formation [17, 18]. Resistance to pitting corrosion of AL-Mg alloys tends to increase or decrease by the presence of alloying elements in aluminium alloys [19, 20]. Al-Mg alloys with more than $3 \% \mathrm{Mg}$ are supersaturated alloys at room temperature. Solute atoms in $\mathrm{Mg}$ tend to be precipitated as $\beta$ phase $\left(\mathrm{Al}_{3} \mathrm{Mg}_{2}\right)$ spreads along the grain boundary of $\mathrm{Al}-\mathrm{Mg}$ alloy at room temperature, during ageing, or during the exposure to high temperature (65-2000 C) [21-23], so Al-Mg alloy like 5083 and 5085 will become sensitized and will be susceptible to corrosion. In this study, the corrosive behaviour of both AA 5083 and AA 5086 marine aluminium alloys have been studied by using the Tafel test. This study was conducted in the Tigris and Shat Al Arab Rivers, at a room temperature of $23^{\circ} \mathrm{C}$. Additionally, the effect of recrystallization annealing on the corrosion behaviour of both AA 5083 and AA 5086 marine aluminium alloys has been studied. The effect of recrystallization annealing on the hardness of AA 5083 and AA 5086 alloys have been also studied.

\section{Experimental Work}

\subsection{Aluminium alloys}

Aluminium alloy grade AA 5083 and AA 5086 have been utilized in this work to investigate their corrosive behaviour in the Tigris and Shat Al Arab Rivers. The chemical composition of aluminium alloys was analyzed by using Spectro max and the results are listed in Table 1 which is fitted to the standard value in reference [24] and reference [25]. The samples with a thickness of $25 \mathrm{~mm}$ were cut using the water jet method. These samples were cut into this thickness to fit the specimen holder dimensions that have been conducted specially for this study. The specimen holder was made of Teflon because Teflon is a slippy material, resists high temperatures and is resistant to almost all chemicals and solvents. The design and dimensions of this specimen holder are shown in figure 1.

Table 1. Chemical composition of (AA 5083 and AA 5086) aluminium alloys in \%

\begin{tabular}{llllllllllll}
\hline Alloy & $\mathrm{Si} \%$ & $\mathrm{Fe} \%$ & $\mathrm{Cu} \%$ & $\mathrm{Mn} \%$ & $\begin{array}{l}\mathrm{Mg} \\
\%\end{array}$ & $\mathrm{Cr} \%$ & $\mathrm{Ni} \%$ & $\mathrm{Ti} \%$ & $\mathrm{Zn} \%$ & $\mathrm{~Pb} \%$ & $\mathrm{Al} \%$ \\
\hline 5083 & 0.15 & 0.368 & 0.022 & 0.417 & 3.8 & 0.140 & 0.002 & 0.019 & 0.010 & 0.019 & 95 \\
5086 & 0.06 & 0.28 & 0.001 & 0.20 & 3.11 & 0.074 & 0.010 & 0.011 & 0.006 & 0.033 & 96 \\
\hline
\end{tabular}




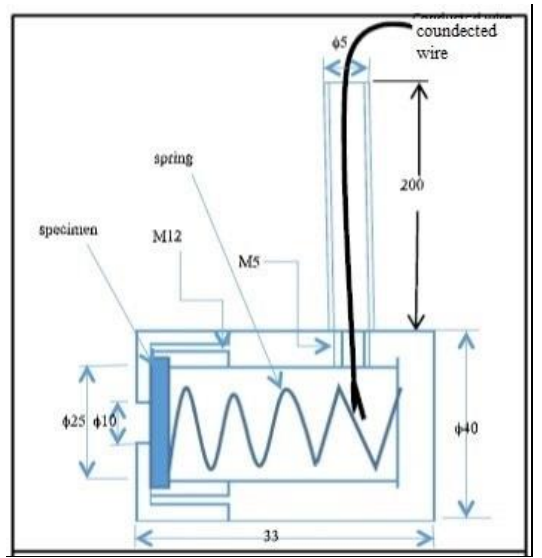

Figure 1. Design and dimensions of the specimen holder. All dimensions are in $\mathrm{mm}$.

\subsection{Water media}

The corrosive behaviour of AA 5083 and AA 5086 marine aluminium alloys was investigated in both Tigris and Shatt $\mathrm{Al}$ Arab water media. Tigris is a River in Iraq that rising in Turkey and flow through Baghdad to the Euphrates in the south-east of Iraq. The two Rivers meet in southern Iraq, forming the Shatt Al Arab which flows into the Gulf.

This study investigates the corrosive behaviour of marine aluminium alloys in the Tigris and Shat Al Arab River at a temperature of $\left(23^{\circ} \mathrm{C}\right)$ and salinity of $(625 \mathrm{mg} / \mathrm{L})$ and $(3254 \mathrm{mg} / \mathrm{L})$ respectively. The chemical analysis of the Tigris and Shat Al Arab Rivers are listed in Table 2.

Table 2. Chemical analysis of Tigris and Shat Al Arab

\begin{tabular}{llllllllllll}
\hline Water media & $\mathrm{PH}$ & $\mathrm{EC}$ & $\begin{array}{l}\mathrm{T} . \mathrm{D} . \mathrm{S} \\
(\mathrm{Mg} / \mathrm{l})\end{array}$ & $\begin{array}{l}\mathrm{CO}_{3} \\
(\mathrm{Mg} / \mathrm{l})\end{array}$ & $\begin{array}{l}\mathrm{HCO}_{3} \\
(\mathrm{Mg} / \mathrm{l})\end{array}$ & $\begin{array}{l}\mathrm{Ca} \\
(\mathrm{Mg} / \mathrm{l})\end{array}$ & $\begin{array}{l}\mathrm{Mg} \\
(\mathrm{Mg} / \mathrm{l})\end{array}$ & $\begin{array}{l}\mathrm{Cl} \\
(\mathrm{Mg} / \mathrm{l})\end{array}$ & $\begin{array}{l}\mathrm{NO}_{3} \\
(\mathrm{Mg} / \mathrm{l})\end{array}$ & $\begin{array}{l}\mathrm{Na} \\
(\mathrm{Mg} / \mathrm{l})\end{array}$ & $\begin{array}{l}\mathrm{K} \\
(\mathrm{Mg} / \mathrm{l})\end{array}$ \\
\hline Tigris River & 7.3 & 955 & 625 & 0.0 & 366 & 47 & 19 & 142 & 1.1 & 115 & 2 \\
Shat Al Arab & 7.48 & 4625 & 3254 & 0.0 & 86 & 280 & 126.68 & 980 & 5.27 & 348 & 161 \\
\hline
\end{tabular}

\subsection{Heat treatment}

In this study, AA 5083 and AA 5086 marine aluminium alloys were annealed by recrystallization annealing to study the effect of heat treatment on the corrosion behaviour of these alloys.

Recrystallization annealing is a heat treatment process that has been used to change the properties 
of cold-worked metals and alloys. For recrystallization annealing, the samples were placed in the lab furnace at a temperature of $\left(350^{\circ} \mathrm{C}\right)$ for $15 \mathrm{~min}$ and then they were cooled down in the air of the furnace.

\subsection{Corrosion test}

The Tafel test has been utilized to study the corrosive behaviour of 5083 and 5086 marine aluminium alloys before and after heat treatment. Before the Tafel test, all samples were ground using emery papers with different grades $(300,500,1000$ and 1500) and then polished by using alumina solution $(5 \mu)$ with a rotation speed of $250 \mathrm{rpm}$ till all the scratches were removed from the surface. The samples were then washed by using water and then etched by using a killer solution (the killer solution is a mixture of hydrofluoric acid, hydrochloric acid and nitric acid that is used to etch aluminium alloys). Samples with $0.78 \mathrm{~cm}^{2}$ exposure surface area were exposed to both the Tigris and the Shat Al Arab Rivers before and after recrystallization annealing. The experimental work was carried out in three-electrode corrosion cells with working electrodes, graphite counter electrodes and calomel reference electrodes.

\subsection{Optical microscope}

In this study, optical microscopes (100X) have been used to identify the microstructure of 5083 and 5086 marine aluminium alloys and the type of corrosion that occurs in these alloys before and after recrystallization annealing.

\section{Results and Dissections}

\subsection{Effect of recrystallization annealing on the microstructure.}

Figure 2 shows the microstructure of both AA 5083 and AA 5086 before and after recrystallization annealing at a temperature of $350^{\circ} \mathrm{C}$ for 15 mins. Figure $2 \mathbf{a}$ and figure $\mathbf{2 b}$ show the microstructure of AA 5083 alloys before and after recrystallization annealing respectively. The microstructure of recrystallized annealed specimens has a larger second precipitate phase than before. Both figures clarify that they are in the same phases. While figures $\mathbf{2 c}$ and $2 \mathbf{d}$ show the microstructures of AA 5086 alloy before and after recrystallization annealing respectively. The microstructure of the recrystallized annealed specimen has a higher amount of second precipitate phase than before. The difference in the microstructure of these alloys is not very large, but the alloying elements in AA 5083 alloy are higher than AA 5086. These alloying elements will affect the mechanical properties after heat treatment more than their effect on the microstructure of AA 5083 and this may result in fine grains. 

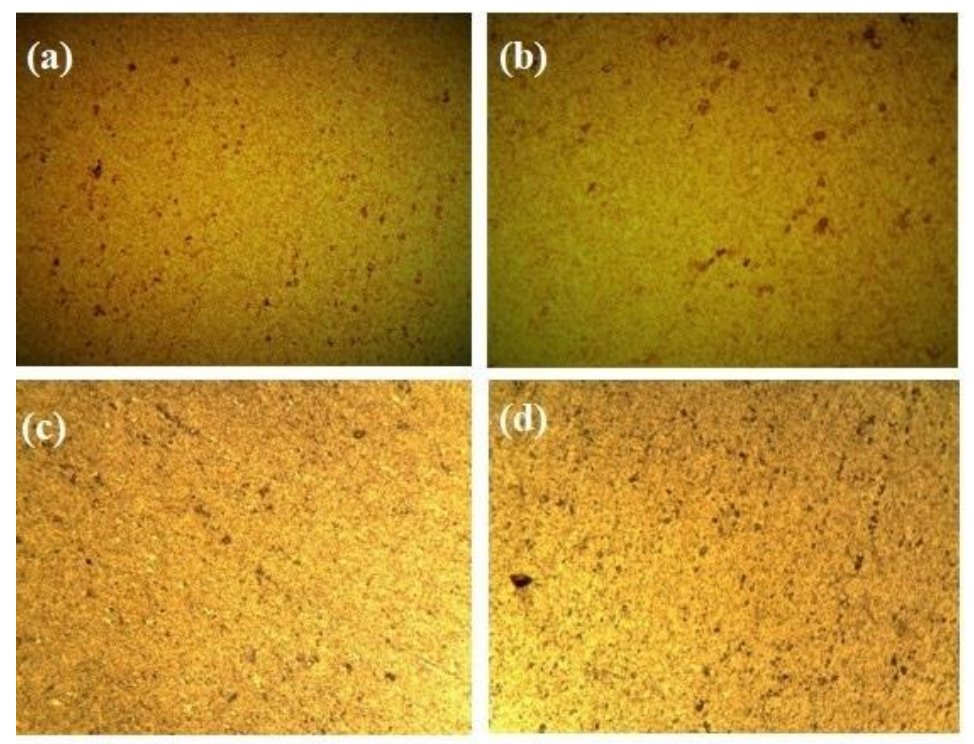

Figure 2. An optical microscope of AA 5083 and AA 5086 marine aluminium alloys: a) AA 5083 as received; b) AA 5083 after recrystallization annealing; c) AA 5086 as received; d) AA 5086 after recrystallization annealing

\subsection{Micro-hardness test}

Table 3 shows the micro-hardness for both marine aluminium alloys before and after recrystallization annealing. The hardness of 5083 alloy shows a decrease in hardness from 84 to $79 \mathrm{VHN}$. This decreasing is due to stress relief which occurs during recrystallization annealing [26]. For 5086 alloy it shows the same behaviour when decreasing hardness from 105 to $98 \mathrm{VHN}$. This is also due to stress relief [27].

Table 3. Microhardness of AA 5083 and AA 5086 marine

\begin{tabular}{lll}
\hline Marine alloy & As received & $\begin{array}{l}\text { Recrystallization } \\
\text { annealing }\end{array}$ \\
\hline AA 5083 & $84 \mathrm{VHN}$ & $79 \mathrm{VHN}$ \\
AA 5086 & $105 \mathrm{VHN}$ & $98 \mathrm{VHN}$ \\
\hline
\end{tabular}




\subsection{Effect of recrystallization annealing on corrosion behaviour of 5083 and 5086 alloys in Tigris River.}

The Tafel test results for both AA 5083 and AA 5086 alloys before and after recrystallization in the Tigris River are shown in figure 3. In figure 3a and Table 4, it is clear that AA 5083 marine aluminium alloy will resist uniform corrosion better than AA 5086 due to the percentage of $\mathrm{Mg}$ in AA 5083 (3.8 \%) which is higher than $\mathrm{Mg}$ value in AA 5086 (3.11\%). The corrosion rate of AA 5083 alloy will decrease as a result of recrystallization annealing as shown in figure $\mathbf{3 b}$ and Table 5 , due to annealing in the range of $230-350^{\circ} \mathrm{C}$ which will improve AA 5083 sensitization [28]. In AA 5086 the corrosion rate will increase due to $\beta\left(\mathrm{Al}_{3} \mathrm{Mg}_{2}\right)$ precipitate along the grain boundary of AA 5086 during the fabrication of the plate [29] which will result in intergranular corrosion, and the disappearance of Ti from the microstructure of AA 5086.

The microstructure of both AA 5083 and AA 5086 after the Tafel test in Tigris are shown in Figure 4. In this figure, both AA 5083 and AA 5086 will suffer from uniform corrosion. Uniform corrosion results from a decrease in thickness over the alloy's surface. The rate of uniform corrosion can range from some microns per year to many microns per hour. This rate depends on the environment and the type of acid in water. Due to low salinity of Tigris River, pitting corrosion does not occur in these alloys.
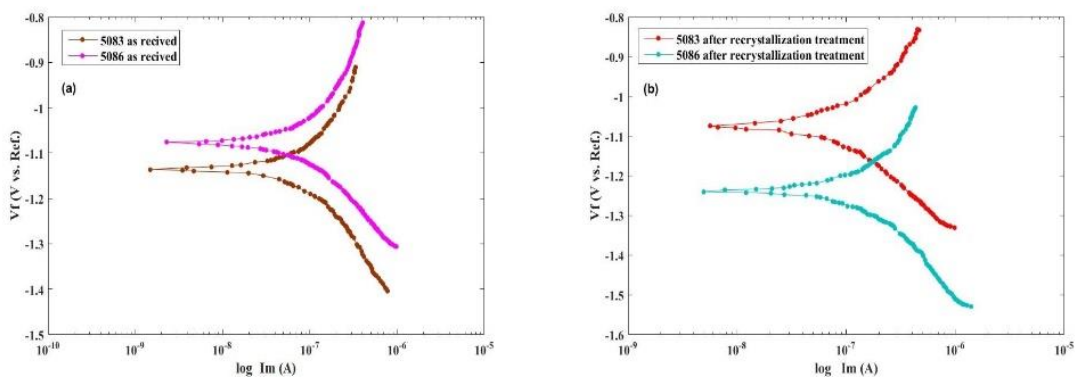

Figure 3. The Tafel test results; a) AA 5083 and AA 5086 alloys as received in Tigris; b) AA 5083 and AA 5086 alloys after recrystallization

Table 4. Data for AA 5083 and AA 5086 in Tigris before recrystallization

\begin{tabular}{llllll}
\hline materials & $\beta_{a}(\mathrm{~V} /$ decade $)$ & $\beta_{c}(\mathrm{v} /$ decade $)$ & $\mathrm{E}_{\text {corr }}(\mathrm{v})$ & $\mathrm{I}_{\text {corr }}(\mathrm{nA})$ & $\mathrm{CR}(\mathrm{mmpy})$ \\
\hline AA5083 & $165.7 \times 10^{-3}$ & $160.7 \times 10^{-3}$ & -1.140 & 61 & $708.5 \times 10^{-6}$ \\
AA5086 & $337.4 \times 10^{-3}$ & $216.8 \times 10^{-3}$ & -1.080 & 108 & $1.259 \times 10^{-3}$ \\
\hline
\end{tabular}


Table 5. Data for AA 5083 and AA 5086 in Tigris after recrystallization

\begin{tabular}{llllll}
\hline Materials & $\beta_{a}(\mathrm{v} /$ decade $)$ & $\beta_{c}(\mathrm{v} /$ decade $)$ & $\mathrm{E}_{\text {corr }}(\mathrm{v})$ & $\mathrm{I}_{\text {corr }}(\mathrm{nA})$ & $\mathrm{CR}(\mathrm{mmpy})$ \\
\hline AA5083 & $156.7 \times 10^{-3}$ & $119.7 \times 10^{-3}$ & -1.070 & 44.4 & $513.3 \times 10^{-6}$ \\
AA5086 & $12.43 \times 10^{-3}$ & $541.6 \times 10^{-3}$ & -1.240 & 639 & $7.418 \times 10^{-3}$ \\
\hline
\end{tabular}
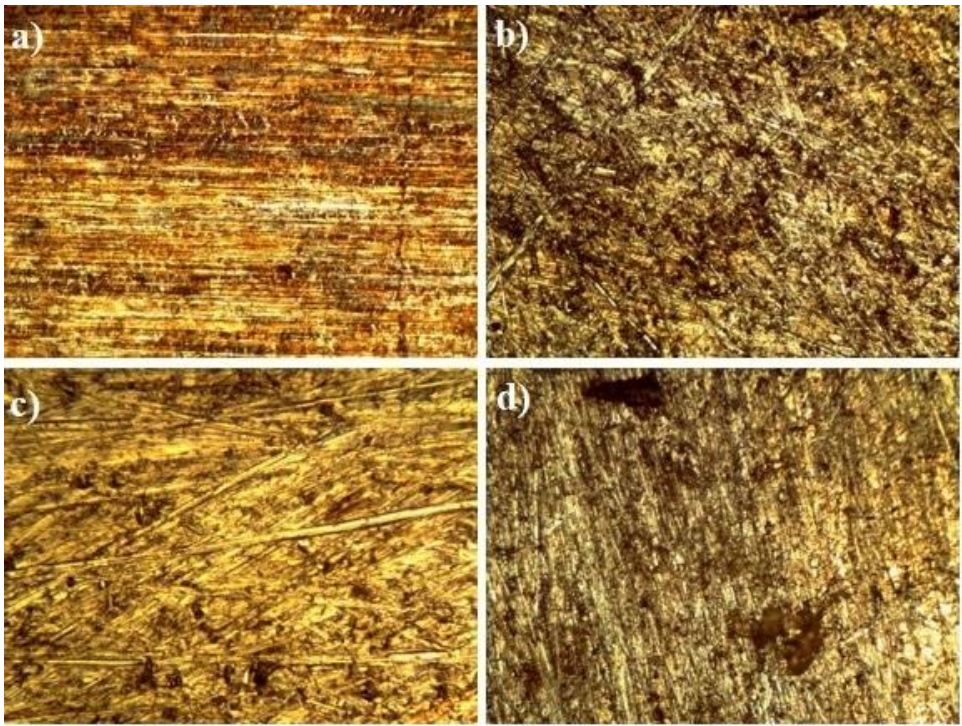

Figure 4. The microstructure of both AA 5083 and AA 5086 after the Tafel test in Tigris; a) AA 5083 alloy as received after the Tafel test; b) AA 5086 alloy as received after the Tafel test; c) AA 5083 alloy after recrystallization and the Tafel test; d) AA 5086 alloy after recrystallization and the Tafel test

\subsection{Effect of recrystallization annealing on corrosive behaviour in Shat Al Arab.}

The Tafel test results for both AA 5083 and AA 5086 alloys before and after recrystallization in Shat Al Arab are shown in figure 5 from figure 6, 5a and Table 6. Both alloys will suffer from uniform corrosion as well as pitting corrosion, but AA 5086 alloy will resist pitting corrosion better than AA 5083, due to different characteristics for intermetallic particles in these alloys [5]. After recrystallization, the pitting resistance of AA 5083 had been improved as shown in figure 5, $6 \mathbf{b}$ and Table 7. Pitting corrosion resistance for AA 5086 had been also decreased after recrystallization. The microstructure of both AA 5083 and AA 5086 after the Tafel test in Shat Al Arab is shown in Figure 6. In this figure, both AA 5083 and AA 5086 will suffer from pitting corrosion due to the 
high salinity of Shat Al Arab in addition to uniform corrosion. The diameter and the depth of this pitting will depend on many factors like alloy type, environments, salt concentration etc.
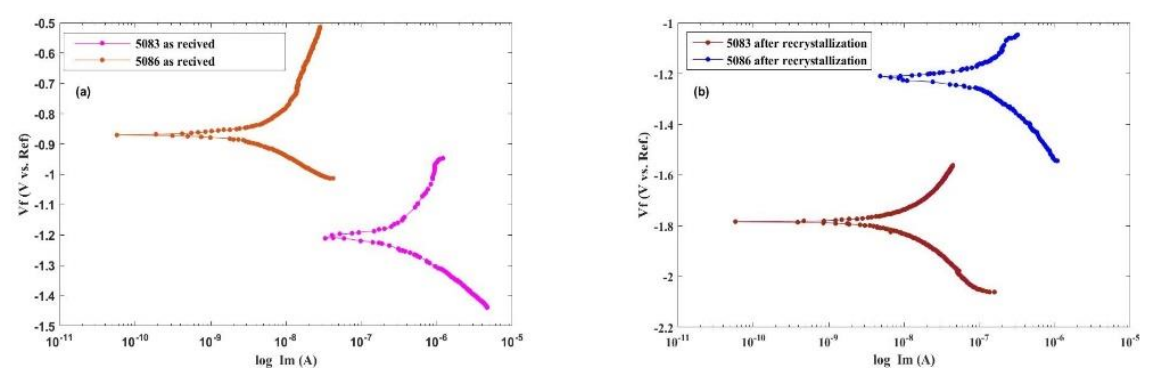

Figure 5. The Tafel test result; a) AA 5083 and AA 5086 alloys as received in Shat Al Arab; b) AA 5083 and AA 5086 alloys after recrystallization in Shat Al Arab.

Table 6. Data for 5083 and 5086 in Shat Al Arab

\begin{tabular}{llllll}
\hline materials & $\beta_{a}(\mathrm{v} /$ decade $)$ & $\beta_{c}(\mathrm{v} /$ decade $)$ & Ecorr $(\mathrm{v})$ & $\mathrm{I}_{\text {corr }}(\mathrm{nA})$ & CR $(\mathrm{mmpy})$ \\
\hline AA5083 & $147 \times 10^{-3}$ & $100.4 \times 10^{-3}$ & -1.210 & 158 & $1.84 \times 10^{-3}$ \\
AA5086 & $91.2 \times 10^{-3}$ & $97.3 \times 10^{-3}$ & -0.868 & 2.43 & $28.25 \times 10^{-6}$ \\
\hline
\end{tabular}

Tabel 7. Data for AA 5083 and AA 5086 in Shat Al Arab after recrystallization

\begin{tabular}{lllllc}
\hline materials & $\beta_{a}(\mathrm{v} /$ decade $)$ & $\beta_{c}(\mathrm{v} /$ decade $)$ & $\mathrm{E}_{\text {corr }}(\mathrm{v})$ & $\mathrm{I}_{\text {corr }}(\mathrm{nA})$ & CR $(\mathrm{mmpy})$ \\
\hline AA5083 & $443.6 \times 10^{-3}$ & $396.6 \times 10^{-3}$ & -1.780 & 18.8 & $217.7 \times 10^{-6}$ \\
AA5086 & $83.5 \times 10^{-3}$ & $78.50 \times 10^{-3}$ & -1.22 & 26.3 & $305 \times 10^{-6}$ \\
\hline
\end{tabular}



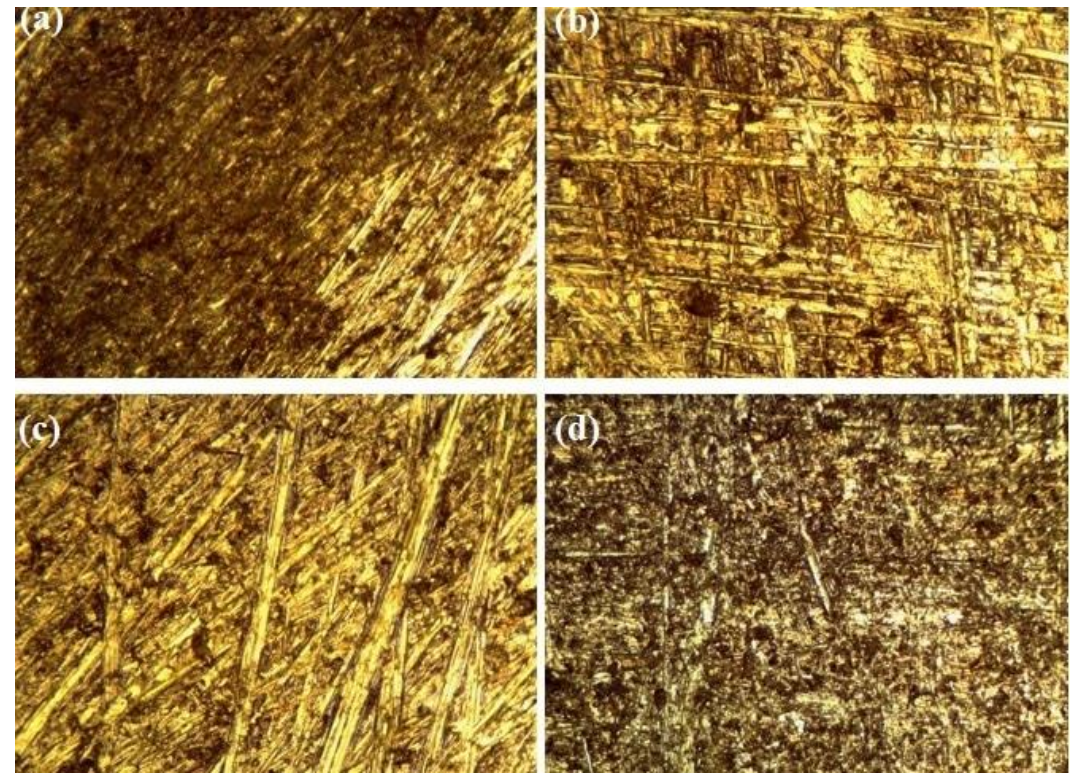

Figure 6. The microstructure of both AA 5083 and AA 5086 after Tafel test in Shat Al Arab; a) AA 5083 alloy as received after the Tafel test; b) AA 5086 alloy as received after the Tafel test; c) AA 5083 alloy after recrystallization and the Tafel test; AA 5086 alloy after recrystallization and the Tafel test

\section{5 cycle polarization in Shat Al Arab}

The AA5083 and AA 5086 cycle polarization curve in Shat Al Arab at room temperature $\left(25^{\circ} \mathrm{C}\right)$ are shown in figure 7. The presented plots show that the properties of the curves are similar to a large degree. This indicates the same reaction on the surface of alloys. In the anodic region, the passive region can be seen in both alloys. This region is formed as a result of the oxide layer on both alloys. The oxide layer decreases the rate of dissolution and acts as a barrier.

The difference in cathodic reaction of AA 5083 and AA 5086 is due to the difference in the amount of dissolved oxygen [30]. The values of $i_{\text {cor }}$ and the rate of corrosion are listed in table 6 . They were obtained by 
using the Tafel test. It can be seen that AA 5083 exhibit higher icor as compared to AA 5086. The dominating type of corrosion of AA 5083 and AA 5086 in saltwater is pitting corrosion. To get more information about pitting potential, cycle polarisation is plotted in figure 7 .

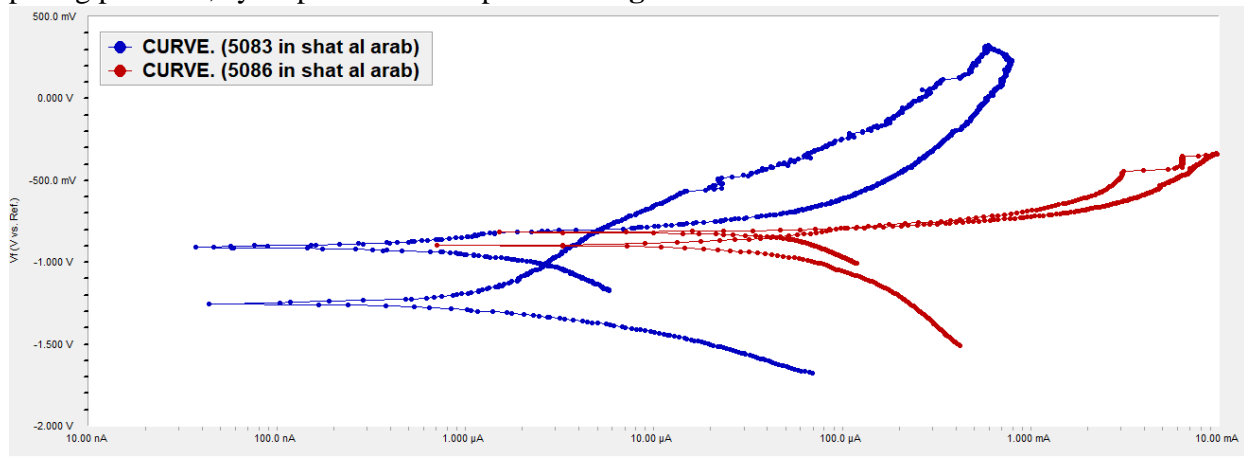

Figure 7. shows the cycle polarization test of AA 5083 and AA 5086 in Shat Al Arab

\section{Conclusion}

1- The Tafel test reveals that both 5083 and 5086 alloys will suffer from uniform corrosion in the Tigris River at room temperature $\left(23^{\circ} \mathrm{C}\right)$ with better corrosion resistance for 5083 alloys.

2- After recrystallization at a temperature of $350^{\circ} \mathrm{C}$ for 15 minutes, the results from the Tafel test show an improvement in corrosion resistance of 5083 alloys while the corrosion resistance of 5086 decreased in both Tigris and Shat Al Arab River.

3- In Shat Al Arab River the Tafel test reveals that both 5083 and 5086 alloys will suffer from pitting corrosion at room temperature $\left(23^{0} \mathrm{C}\right)$ with better corrosion resistance for 5086 alloys.

\section{Acknowledgements}

The authors would like to thank the staff of Mustansiriyah University (www.upomustansiriyah.edu.iq)

Baghdad-Iraq, for their support in the present work.

\section{References}

[1] Bakhtiarinejad, A., Ranjbar, K., Ashrafi, A., Rezaei, B.: Pitting corrosion and metastable pitting initiation rate of 5083 aluminium alloy in synthetic seawater as a function of medium ph. conference proceedings. 23rd International Conference on Metallurgy and Materials METAL. (2014) 
[2] Vetrano, J.S., Bruemmer, S.M., Pawlowski, L., Robertson, I.: Influence of the particle size on recrystallization and grain growth in Al-Mg-X alloys. Materials Science and Engineering A. Vol. 238. pp. 101-107 (1997)

[3] Sanders Jr, R., Hollinshead, P., Simielli, E.: Industrial development of non-heat treatable aluminium alloys. conference proceedings. Materials Forum. (2004)

[4] Freeman, S., Green, J.: Aluminium in the marine environment: An update. conference proceedings. OCEANS 2000 MTS/IEEE Conference and Exhibition. Conference Proceedings (Cat. No. 00CH37158). (2000)

[5] Ezuber, H., El-Houd, A., El-Shawesh, F.: A study on the corrosion behavior of aluminium alloys in seawater. Materials and Design. Vol. 29. pp. 801-805 (2008)

[6] MacKenzie, D.S., Totten, G.E., Analytical characterization of aluminium, steel, and superalloys, CRC press2005.

[7] Sivam, S.S.S., Kumar, A.L., Moorthy, K.S., Kumar, R.: Investigation Exploration Outcome of Heat Treatment on Corrosion Resistance of AA 5083 in Marine Application. International Journal of Chemical Sciences. Vol. 14. pp. 453-460 (2016)

[8] Behnagh, R.A., Besharati Givi, M., Akbari, M.: Mechanical properties, corrosion resistance, and microstructural changes during friction stir processing of 5083 aluminium rolled plates. Materials and Manufacturing Processes. Vol. 27. pp. 636-640 (2012)

[9] Canepa, E., Stifanese, R., Merotto, L., Traverso, P.: Corrosion behaviour of aluminium alloys in the deep-sea environment: A review and the KM3NeT test results. Marine Structures. Vol. 59. pp. 271-284 (2018)

[10] Davis, G., Shaw, B., Rees, B., Ferry, M.: Mechanisms of Passivity of Nonequilibrium Al-W Alloys. Journal of the Electrochemical Society. Vol. 140. pp. 951-959 (1993)

[11] Carroll, W., Breslin, C.: Stability of passive films formed on aluminium in aqueous halide solutions. British Corrosion Journal. Vol. 26. pp. 255-259 (1991)

[12] Shaw, B., Davis, G., Fritz, T., Rees, B., Moshier, W.: The influence of Tungsten alloying additions on the passivity of Aluminium. Journal of the Electrochemical Society. Vol. 138. pp. 32883295 (1991)

[13] McCafferty, E.: Crevice corrosion and pitting. VOL. pp. 263-313. Springer, Published (2010)

[14] Ghali, E., Corrosion resistance of aluminium and magnesium alloys: understanding, performance, and testing, John Wiley \& Sons2010.

[15] Szklarska-Smialowska, Z.: Pitting corrosion of aluminium. Corrosion Science. Vol. 41. pp. 1743-1767 (1999)

[16] Davis, J., Gehring, G.: The effect of velocity on the seawater corrosion behavior of highperformance ship materials. Materials Performance (MP). Vol. 14. pp. (1975)

[17] Aballe, A., Bethencourt, M., Botana, F., Cano, M., Marcos, M.: Localized alkaline corrosion of alloy AA5083 in neutral 3.5\% NaCl solution. Corrosion Science. Vol. 43. pp. 1657-1674 (2001) [18] eL-Deeb, M.M.: Role of S 2- ions on the microstructure change and the pitting behaviour of aluminium in saline solution. Scientific Reports. Vol. 9. pp. 1-10 (2019)

[19] Srinivasan, H.S., Mital, C.: Studies on the passivation behaviour of al-Zn-Mg alloy in chloride solutions containing some anions and cations using electrochemical impedance spectroscopy. Electrochimica Acta. Vol. 39. pp. 2633-2637 (1994)

[20] Holroyd, N.H.: Aluminium alloys. VOL. pp. 179-257. CRC Press, Published (2001) 
[21] Scamans, G., Holroyd, N., Tuck, C.: The role of magnesium segregation in the intergranular stress corrosion cracking of aluminium alloys. Corrosion Science. Vol. 27. pp. 329-347 (1987)

[22] Searles, J., Gouma, P., Buchheit, R.: Stress corrosion cracking of sensitized AA5083 (Al-4.5 Mg-1.0 Mn). Metallurgical and Materials Transactions A. Vol. 32. pp. 2859-2867 (2001)

[23] Jones, R., Baer, D., Danielson, M., Vetrano, J.: Role of Mg in the stress corrosion cracking of an Al-Mg alloy. Metallurgical and Materials Transactions A. Vol. 32. pp. 1699-1711 (2001)

[24] AZO MATERIALS, Aluminium 5083 is known for exceptional performance in extreme environments. Aluminium 5083 is highly resistant to attack by both seawater and industrial chemical environments. $<$ https://www.azom.com/article.aspx?ArticleID=2804>, 2005,April 19).

[25] AZO MATERIALS, Aluminium / Aluminium 5086 Alloy (UNS A95086). <https://www.azom.com/article.aspx?ArticleID=6631>, 2012, September 27).

[26] Lee, Y.B., Shin, D.H., Park, K.-T., Nam, W.J.: Effect of annealing temperature on microstructures and mechanical properties of a $5083 \mathrm{Al}$ alloy deformed at cryogenic temperature. Scripta Materialia. Vol. 51. pp. 355-359 (2004)

[27] Rana, R., Purohit, R., Das, S.: Reviews on the influences of alloying elements on the microstructure and mechanical properties of aluminium alloys and aluminium alloy composites. International Journal of Scientific and Research Publications. Vol. 2. pp. 1-7 (2012)

[28] Chen, R.-Y., Chu, H.-Y., Lai, C.-C., Wu, C.-T.: Effects of annealing temperature on the mechanical properties and sensitization of 5083-H116 aluminium alloy. Proceedings of the Institution of Mechanical Engineers, Part L: Journal of Materials: Design and Applications. Vol. 229. pp. 339-346 (2015)

[29] Bovard, F.S.: Sensitization and environmental cracking of 5XXX aluminium marine sheet and plate alloys. Corrosion in Marine and Saltwater Environments II. Vol., pp. 232-243 (2005)

[30] Lokas, L., Alar, V.: The effect of temperature on corrosion behavior of AA5083 in brackish water and seawater. Materials and Corrosion. Vol. 70. pp. 1817-1825 (2019) 